\title{
An ESP Learning Materials for Students of Midwifery
}

\author{
Kadek Heni Oktarina Wisudayanti \\ STKIP Agama Hindu Singaraja, Bali, Indonesia \\ Email: kadekoktarina09@gmail.com
}

\begin{abstract}
As an international language, English plays an important role as a means of communication. English as a tool and as an opportunity to support the future development. Therefore, English as a crucial subject in almost all education levels. One of term that concern with this condition is English for Spesific Purposes (ESP). This research aimed at developing an ESP learning material for students of Midwifery. This study used Research and Development combine the design by R \& D design by Dick and Carey model (2005) and Borg and Gall (2003). The result showed that the learning English could be classified as English for Specific Purpose (ESP). English for Specific Purpose (ESP) is in line with the curricular objectives, which is modelled in terms of standard competency, basic competency and learning indicators. Following the competencies and learning indicators. Therefore, the detailed learning materials would be described in terms of (1) language function, (2) language features, and (3) text structures. Moreover, the result of questionnaire showed the students' positive responses toward the learning materials. The learning materials were also proven effectively improve students' speaking abilities after the implementation of the learning materials. The developed learning materials is good for English learning for students of Midwifery because it accomodates the needs of the students in their students teaching and learning process of ESP lesson.
\end{abstract}

Keywords: English for Specific Purposes (ESP); ESP Material: Material Development

\section{INTRODUCTION}

In the development of global communication and information era, English starts to play an important role in the social and economic aspects. As an international language, English plays an important role as a means of communication. English as a tool and as an opportunity to support the future development. Therefore, English as a crucial subject in almost all education levels. One of term that concern with this condition is English for Specific Purposes (ESP). Hutchison and Waters (1987) state that ESP as an approach rather than product. They state that ESP is an approach to language learning which is based on learners' needs. It is true that ESP comes from the demand of the learner. Thus, the teacher should have knowledge 
of the relevant technical field. It can be argued that ESP really needs a language structure of its own to be taught properly and the teacher, therefore, requires some knowledge of the specific subject area as well. According to Saragih ESP is a movement based on the proposition that all language teaching should be tailored to the specific learning and language use needs for identified group or learners (2014) .It is also sensitive to the socio-cultural contexts in which these learners use English ESP is focused on a learner centered approach, since it meets the needs of adult learners who need to learn a foreign language for use in their specific fields: such as science, leisure, medicine, economics, technology and academic learning. It can be concluded that, ESP program needs to be develop for there is a need for language courses in which certain contents, skills, motivations and processes are identified and integrated into specialized courses.

In education, Eisner (2004) states that a curriculum is a set of courses and their contents offered by an institution such as a school or university. The term curriculum may relate to the range of courses that students can select from a specific learning program. A crucial of the curriculum is 1) the course objectives which are often expressed in terms of learning outcome or competencies, 2) instructional material, 3) learning approach, method, and techniques, 4) learning time allotment, 5) learning resources and media, and 6) evaluation of learning processes and outputs. According to Longstreet and Shane (2008), there are numerous factors determining the success of teaching learning process. There are many factors which should be taken into account. One of those is by providing relevant English learning materials. It means that English learning materials can be seen as an exposure to the use of the language which will help them in achieving the higher proficiency of English. Unfortunately, materials which are relevant or even appropriate to the needs of the students. Materials for language learning refer to things that can help students to learn the language. Tomlinson (1998) states that the materials include books, videos, graded reades, flash cards, games, websites and mobile phone interactions, though, inevitably, much of the literature focuses on printed materials. As materials become the source of learning, it is beneficial for the teachers to provide good and appropriate materials to be given to the students.

\section{METHOD}

Research and Development (R \& D) combine the design by Dick and Carey model (2005) and Borg and Gall (2003) were used in this research. The researcher synthesized the model of developing English learning materials into 7 steps: (1) Needs analysis learning material profile's, (2) Planning and design learning material profile's, (3) Conceptual Learning material development, (4) Professional Expert Validation, (5) Empirical learning material, (6) Learning material revision, and (7) Revision of final learning material and learning material development. In this research the data were collected using some methods, namely questionnaire, interview and document analysis. Firstly, in relation to need analysis, questionnaire can be used to collect data for target situation analysis. The needs analysis questionnaire was used to gather the data of the target and learning needs in English. In this case 
the lecturers and the midwives at the international hospital. The lecturers and the midwives at the international hospital were asked to answer several questions related to their characteristics and needs in learning English by choosing one or more options from several options provided. However, they were also allowed to give other answers related to the questions. Secondly, interview was done to give additional data and make sure that the researcher obtained consistent data. It was done during identification of problem and potential. Thirdly, according to Robinson authentic data analysis is one of the techniques for need analysis (1991) In this case, the analysis was done to printed materials or related documents, such as existing syllabus in STIKes Buleleng that is used in teaching learning process in DIII Midwifery STIKes Buleleng.

The process in the data analysis method are: first, the analysis was done to printed materials or related documents, such as existing syllabus in STIKes Buleleng that is used in teaching learning process in DIII Midwifery. Secondly, in relation to need analysis, questionnaire can be used to collect data for target situation analysis. In this case, the needs analysis questionnaire was used to gather the data of the target and learning needs in English, especially to find out what are the appropriate topic in the learning materials for student of Midwifery at STIKes Buleleng. Third, the process of data analysis method was carried out the conceptual English Learning Materials for Midwifery suitably developed at STIKes Buleleng to the professional evaluation, the learning material evaluation by expert judgements and teacher. After being sorted, the data should be displayed. Displays are presented in tables, graphs and.charts, however narrative reports were also used to describe the data in the table. The last process of data analysis is conclusion. In this step, the researcher concludes the data, it relates to research problem. Then, making a conclusion which is appropriate.

\section{RESULTS AND DISCUSSION}

In this stage, the following point of Hutchinson and Waters' framework for target need analysis is the content area of the language. In order to ESP need analysis, the content area is the subject area. In here, the researcher took out some possible topics related to English for Midwifery. There were 10 topics given by the researcher. The result of the questionnaire shows that there are some topics related to English for Midwifery.

Based on the questionnaire handed out, it found that $100 \%$ respondents agree that Asking and Filling Patient's Medical Report is an important the topics in English for Midwifery and 12\% were neutral and $0 \%$ disagree with the statements. The second topic, Giving Instruction to the Patient, got $100 \%$ of agreement. Meanwhile, each of the important topics, Explaining Medication, Giving Advice to the Patient, Explaining Prescription and Giving Direction got 100\% voice of agreement. The result of the questionnaire shows that there are some topics related to English for Midwifery. The topics are the situations that might occur during handling patient. Based on the questionnaire handed out, it also found that $100 \%$ respondents agree that Asking and Filling Patient's Medical Report is an important the topics in English for Midwifery and $0 \%$ were neutral and disagree 
with the statements. The second topic, Giving Instruction to the Patient, got $100 \%$ of agreement and $0 \%$ diagreement. Meanwhile, each of the important topics, Explaining Medication, Giving Advice to the Patient, Explaining Prescription and Giving Direction got 100\% voice of agreement and $0 \%$ diagreement. The second stage, in relation to the quality of the developed learning materials for teaching English for students of Midwifery at STKES Buleleng of the materials development was learning materials evaluation. It was evaluated by experts and revision was done after the product has been judged. The learning materials were developed into 6 unit lessons. The learning materials are consisted of three major aspects, namely: language features, language functions, and text structures. Language features include phonological, lexical, syntactical and semantic items. While language functions focus on speech acts with their specific locutionary acts. The speech acts and their locutionary acts include 1) Assertives with their varying acts such as suggesting, 2) Directives with their varying acts such requesting, questioning, commanding, prohibiting, and, advising.

Table1. The result of need analysis questionnaire related to content area of the language

\begin{tabular}{|c|l|c|c|c|}
\hline \multicolumn{2}{|l|}{ The content area } & Agree & Neutral & Disagree \\
\hline \multirow{4}{*}{} & $\begin{array}{l}\text { Introducing and Establishing a } \\
\text { Relationship to the Patients }\end{array}$ & $52 \%$ & $12 \%$ & $0 \%$ \\
\cline { 2 - 5 } & $\begin{array}{l}\text { Asking and Filling Patient's Medical } \\
\text { Report }\end{array}$ & $100 \%$ & $0 \%$ & $0 \%$ \\
\cline { 2 - 5 } Topic & Educating Patients & $28 \%$ & $0 \%$ & $72 \%$ \\
\cline { 2 - 5 } & Giving Instruction to the Patient & $100 \%$ & $0 \%$ & $0 \%$ \\
\cline { 2 - 6 } & Explaining Medication & $100 \%$ & $0 \%$ & $20 \%$ \\
\cline { 2 - 5 } & Making Telephone Call & $80 \%$ & $0 \%$ & $0 \%$ \\
\cline { 2 - 5 } & Giving Advice to the Patient & $100 \%$ & $0 \%$ & $40 \%$ \\
\cline { 2 - 5 } & Handling Patient's Admission & $60 \%$ & $0 \%$ & $40 \%$ \\
\cline { 2 - 5 } & Giving Medical Treatment & $60 \%$ & $0 \%$ & $0 \%$ \\
\cline { 2 - 5 } & Explaining Prescription & $100 \%$ & $0 \%$ & $0 \%$ \\
\cline { 2 - 5 } & Giving Direction & $100 \%$ & $0 \%$ & $0 \%$ \\
\hline
\end{tabular}


The learning activities follow the Communicative Approach. The specific learning activities included in the learning materials consist of pre activity, whilst activity (exploration, elaboration and confirmation), and post activity. Based on the professional evaluation the conceptual English Learning Materials for Midwifery suitably developed at STIKes Buleleng, the learning material evaluation by expert judgements the materials belongs to good material with the materials scored 89.5 and the learning material evaluation by teacher, the materials belongs to excellent material with the learning materials scored 97,5. There were increases in the mean score of the students from before the developed materials were implemented to first, second and third session. It rose from 79,03 to 82,83 on the first sessions, to 84,76 after the second sessions, and 86,43 at the end of the sessions. It means that the developed materials could improve the speaking ability of the students general; supporting the judegement saying the mterials were excellent. However the weakness of this study was that the learning material was only implemented in one class. It means that could not represent the ability of the students Midwifery in STIKES Buleleng.

\section{CONCLUSION AND SUGGESTIONS}

The curricular needs of the students in learning English at STIKES Singaraja was assessed prior to the analysis. The curricular needs were assessed from the School-based Curriculum, the syllabus and Lesson Plan. The assessed needs of standard competency, basic competency and learning indicators were then analyzed in terms of descriptive profiles. Following the competencies and learning indicators, therefore, the detailed learning materials would be described in terms of (1) language function, (2) language features, and (3) text structures. The model of ESP material design of Hutchinson and Waters [3] which consists of input, content focus, language focus and task was also adopted as the framework of material design in the learning material of English for Midwifery at STIKes Buleleng. The tasks consist of individual, pair, group and also the Grammar's task. There are some suggestion that can be given to some parties in relation to this study, namely other researchers as well as English teachers especially those teaching English for Midwifery. First, to other researcher. This present study was limited in speaking materials for teaching English for Midwifery in STIKes Buleleng. It was made the sake of teaching ESP in the Midwifery department in the institution. Other researcher can try to implement the materials in more classes in STIKes Buleleng or even larger area to see whether or not the materials are effectve for teaching speaking in English for Midwifery lesson in other colleges. Moreover, other researcjers can also do similar research of materials development for teaching English in other field such as English for Nurses and English for Paramedic or any other ESP which is beneficial for students in their future career. Second to the teachers of English for Midwifery. It is suggested that English teachers in the institution can make use of the develop materials to support teaching and learning process in STIKes Buleleng in rorder to help students to be able to communicate in English. 


\section{REFERENCES}

T. Hutchinson, A.Waters. 1987. English for Spesific Purposes: A Learning-Centred Approach. Cambridge: Cambridge University Press.

E. Saragih, Designing ESP Materials for Nursing Students Based on Needs Analysis. International Journal of Lingusitic, 6(4). Retrieved on August, 20, 2020 at http://www.macrothink.org/journal/index.php/ijl/ article/download/5953/pdf(2014)

E. Eisner. 2004. The educational imagination: On design and evaluation of school; programs. (3rd, ed) New York: Macmillan
W. S. Longstreet, and H.G. Shane. 2008. Curriculum for a new millenium. Boston: Allynand Bacon

B. Tomlinson. 1998. Materials Development in Language Teaching. Cambridge: Cambridge University Press.

W. Dick \& L. Carey. 2005. The Systematic Design of Instruction. USA: Scoot, Foresman and Company

M. Gall, et all 2003. Educational Research: An Introduction. United States of America: Pearson Education Inc. (2003).

C. Robinson. 1991. ESP Today: A Practitioner Guide. Great Britain: Prentice Hall 